$12-21-2020$

\title{
Book Review: Extraordinary Justice: Law, Politics, and the Khmer Rouge Tribunals
}

Suzanne Schot

University of Groningen, the Netherlands

Follow this and additional works at: https://digitalcommons.usf.edu/gsp

\section{Recommended Citation}

Schot, Suzanne (2020) "Book Review: Extraordinary Justice: Law, Politics, and the Khmer Rouge Tribunals," Genocide Studies and Prevention: An International Journal: Vol. 14: Iss. 3: 129-131.

DOI:

https://doi.org/10.5038/1911-9933.14.3.1793

Available at: https://digitalcommons.usf.edu/gsp/vol14/iss3/11

This Book Review is brought to you for free and open access by the Open Access Journals at Digital Commons @ University of South Florida. It has been accepted for inclusion in Genocide Studies and Prevention: An International Journal by an authorized editor of Digital Commons @ University of South Florida. For more information, please contact digitalcommons@usf.edu. 


\title{
Book Review: Extraordinary Justice: Law, Politics, and the Khmer Rouge Tribunals
}

\author{
Suzanne Schot \\ Rijksuniversiteit Groningen \\ Groningen, The Netherlands
}

\author{
Extraordinary Justice: Law, Politics, and the Khmer Rouge Tribunals \\ Craig Etcheson \\ New York, Columbia University Press, 2019 \\ 470 Pages; Price: \$63.78 Hardcover
}

Reviewed by Suzanne Schot

University of Groningen, The Netherlands

In Extraordinary Justice: Law, Politics and the Khmer Rouge Tribunals, ${ }^{1}$ Craig Etcheson combines his personal experience as chief of investigations in the Office of Co-Prosecutors at the Extraordinary Chambers in the Courts of Cambodia (ECCC) with research he undertook for more than two decades to analyze how the relationship between law and politics may explain the creation and functioning of war crimes tribunals. In particular, Etcheson presents a detailed analysis of how Cambodians and the international community sought to bring Khmer Rouge leaders to justice by emphasizing the relationship between these two distinct, yet intertwined, concepts.

The thread throughout the book is based on the analytical framework presented in the introduction, which considers ideological approaches to the relationship between law and politics. Etcheson distinguishes between three general approaches, namely classic legalism, strategic legalism, and instrumental legalism, which differ in their orientation towards the influence of politics. Given the implications of this framework for understanding the development and functioning of past, present, and future war crimes tribunals, there are many reasons why those interested in the ECCC and war crimes tribunals more broadly are encouraged to read this book; of which a few are discussed below.

The book devotes attention to many facets which explain how the ECCC eventually came into existence and how it operates as a result of the struggles between the three ideologies mentioned above. Before attention is drawn to the ECCC, however, Etcheson considers how Cambodia reconstructed its legal system after the fall of the Khmer Rouge in 1979 and which legal ideologies inspired its reformed legal system. Hereafter Etcheson addresses the dynamics at play when the People's Revolutionary Tribunal (PRT) was set-up to prosecute two leaders of the Khmer Rouge for genocide in 1979. Both the criticism the Tribunal faced in relation to its legitimacy and effectiveness, as well as the legal challenges the Tribunal encountered are discussed. Etcheson analyses how this Tribunal, its proceedings, and aftermath nevertheless led to negotiations that would eventually lead to the creation of the ECCC.

The negotiations that took place in order to create the ECCC form a large part of this book. Etcheson considers in great length and detail the negotiations that took place between Cambodia and the UN, which eventually led to an agreement to create a mixed tribunal. Particular attention is devoted to the tension between ensuring international standards and respecting Cambodian sovereignty. As Etcheson indicates, "the ECCC would be established in cooperation with the UN, but the international standards in legal affairs that the UN sought to protect was at odds with the Cambodian insistence on maintaining political control over judicial

\footnotetext{
${ }^{1}$ Craig Etcheson, Extraordinary Justice: Law, Politics and the Khmer Rouge Tribunals (New York: Columbia University Press, 2019).
} 
proceedings." 2 The subsequent tension between Cambodia and the UN led to another two years of negotiations, hereby "making it much less likely that aging potential defendants would survive long enough to see their day in court." 3 Other negotiations addressed by Etcheson include those that took place over the budget of the ECCC, its venue, and how the court would be, and eventually was, staffed. In addition to the negotiations that took place, the book also offers an analysis of the more legal challenges that occurred before, during, and after the initiation of proceedings before the ECCC. Legal and evidentiary challenges and opportunities surrounding the investigation and prosecution of crimes committed by the Khmer Rouge are meticulously analyzed by Etcheson, and he in particular discusses defense strategies and their implications for proceedings.

In his conclusion, Etcheson also critically engages with discussions on the legacy of the ECCC and whether there should be follow-up transitional justice activities in the wake of the ECCC. In relation to the legacy of the ECCC, he remarks that almost none of the evidence admitted at trial has been released to the public via the courts website or through any other means, and stresses the importance of making this evidence available for historians and other researchers. ${ }^{4}$ Although not explicitly mentioned, victims and witnesses may, of course, also have an interest in the public availability of the evidence admitted at trial.

Etcheson's analysis of the relationship between law and politics offers not only a framework to understand the dynamics at play when individual criminal responsibility is sought for those who commit international crimes, such as genocide, but it also draws attention to the significant lapse of time that may occur as a result of the struggles inherent to the confrontation between the three general ideologies presented in the introduction. As mentioned above, Etcheson found that the time that passed as a result of negotiations made it less likely that aging potential defendants would survive long enough to see their day in court. The lapse of time therefore raised the important question who could still be prosecuted. The number of individuals who would eventually be indicted by the ECCC would be determined, amongst others, by precisely this. As Etcheson mentions, "one thing that made these decisions a little easier for the co-prosecutors was the fact that thirty years after the fall of the Khmer Rouge regime, there were simply not many senior leaders remaining alive to answer criminal charges." 5 This may indeed make the decisions a little easier for the co-prosecutors or others involved in the prosecution of the crimes, but for the victims and witnesses this may mean that justice will have been delayed and may therefore be denied.

This may lead the reader to question how the concepts or 'justice' or 'truth' may also play a role in the framework of law and politics the author offers throughout his analysis. In the introduction, Etcheson writes that one of the things he learned along the way "is that certain words, words that may seem quite simple from the face of it - like 'truth', 'justice', and 'law' are in fact very complicated. They mean different things to different people. Consequently, getting people to agree on them can be exceedingly difficult and time-consuming." 6 Although the book is already extraordinarily detailed in its analysis of the relationship between law and politics, a (brief) critical analysis of how these concepts may also be intertwined with how war crimes tribunals come into existence, operate and unfold would have been interesting. Even more so since they are briefly addressed in the introduction and draw attention to very fundamental concepts underlying international criminal justice.

Built on personal experiences and scholarly research, the book makes a significant contribution to existing scholarship on not only the ECCC, but also transitional justice more broadly. This is predominantly a result of Etcheson's approach towards the relationship between law and politics and how he incorporates and intertwines his findings with primary

\footnotetext{
2 Ibid., 99.

${ }^{3}$ Ibid., 100.

${ }^{4}$ Ibid., 348.

${ }^{5}$ Ibid., 198-199.

${ }^{6}$ Ibid., $2-3$.
} 
sources and anecdotes. Key lessons can be learned from the book about the dynamics between law and politics in the creation and functioning of war crimes tribunals. This makes the book essential for a broad audience, including academics and practitioners with an interest in international criminal law, transitional justice, the ECCC, and potentially those working in the field of international relations and international organizations. 